\title{
A retrospective cross-sectional survey on nosocomial bacterial infections and their antimicrobial susceptibility patterns in hospitalized patients in northwest of Iran
}

Hamid Sadeghi', Saeideh Gholamzadeh Khoei ${ }^{2}$, Mehdi Bakht ${ }^{3}$, Mohammad Rostamani $^{3}$, Sara Rahimi ${ }^{3}$, Mehdi Ghaemi ${ }^{4}$ and Bahman Mirzaei ${ }^{1,5^{*}}$ (])

\begin{abstract}
Objective: Nosocomial infections (NIs) are known as one of the remarkable problems in all countries. This study is aimed to estimate the prevalence rate of nosocomial bacterial agents with antimicrobial susceptibility pattern in hospitalized patients. This study was conducted from April 2017 to September 2018, on 4029 hospitalized patients. We set out to recognize the commonest bacterial infections and antimicrobial susceptibility patterns of nosocomial infection.

Results: Of the 4029 patients, 509 (12.6\%) of them were culture positive. Of these Escherichia coli (E. coli) (98.3\%) and Staphylococcus epidermidis (S. epidermidis) (37.5\%) were the most abundant bacterial identified in the urinary tract and bloodstream cultures respectively, Moreover, Acinetobacter spp. (100\%) and Pseudomonas aeruginosa (22.2\%) were the most abundant organisms detected in the respiratory system. According to susceptibility testing results, 370 (80.5\%) and 264 (57.3\%) in Gram-negatives and 44 (91.7\%) and 35 (72.9\%) in gram positives isolated strains were classified as multidrug-resistant (MDR) and extensive drug-resistant (XDR) strain respectively. On account of the high prevalence of MDR and XDR bacterial species, there is a pressing need for the expansion of new strategies on antibiotic supervision and infection control to introduce new guideline on empirical antibiotic therapy.
\end{abstract}

Keywords: Nosocomial infections, Bacterial isolates, Susceptibility patterns, Multi-drug resistant (MDR), Extensivelydrug resistant (XDR)

\section{Introduction}

Nosocomial infections (NIs) are known as hospitalgained infection expanding within 48-72 $\mathrm{h}$ after incoming [1]. A large part of morbidity and mortality in hospitals goes back to the NIs [2]. Following the increasing rate of NIs, developing in socio-economic disturbance, antimicrobial resistance, and the mortality rate are inevitable [3]. NIs happen throughout the world both

*Correspondence: dr.bahman.m@gmail.com; drbahman@zums.ac.ir 1 Department of Microbiology and Virology, School of Medicine, Zanjan University of Medical Sciences, Zanjan, Iran

Full list of author information is available at the end of the article in developing and developed countries. NIs accounts for $10 \%$ in developing and 7\% in developed countries [4]. Nearly 2 million people have been tangled in this matter and also would be known as a major reason for the loss of life and money [5]. Bacteria are hugely the prominent cause of NIs [6]. The most usual kinds of NIs which happen in a hospital set up are: urinary system, bloodstream infections, surgical site infections, gastroenteritis, respiratory system $[7,8]$. Despite global endeavor to rein NIs during previous years, NIs still stays a widespread problem and as one of the important causes of antibiotic resistance in hospitalized patients [9]. As antibiotic resistance continues to greaten, attuned definitions with which 
to characterize and recognize multiple resistant bacteria to antimicrobial agents are indispensable; therefor epidemiological information can be trustworthily gathered and compared among healthcare settings and countries [1013]. In verbal terms, multidrug-resistant (MDR) means 'resistant to more than one antimicrobial agent', but no standardized descriptions for MDR have been come to an agreement upon yet by the medical community $[14,15]$. Extensive drug-resistant (XDR) Bacteria are epidemiologically remarkable in two reasons: resistance to multiple antimicrobial agents and resistance to all, or almost all, approved antimicrobial agents $[16,17]$. In another definition MDR means non-susceptibility to at minim one agent in three or more antimicrobial categories, XDR means non-susceptibility to at minim one agent in all but two or fewer antimicrobial categories [18]. In bacteria, integrons as transposable elements and extended spectrum $\beta$-lactamases (ESBLs) enzymes in a variety of Gram negative bacteria are related to an increased resistance to commonly used antibiotics [19-21]. There is no denying the fact that if there is no efficient timely respond, the problem of resistance to antibiotic is becoming a huge difficulty in the future years. Therefore, the aims of this study were to estimate the prevalence rate of nosocomial bacterial agents with antimicrobial susceptibility patterns in hospitalized patients referred to Emdadi Hospital, Abhar, Iran.

\section{Material and methods}

\section{Study area, study period and study population}

This retrospective cross-sectional study was conducted on 4029 patients from April 2017 to September 2018 in the Emdadi Hospital, Abhar, Iran. NIs criteria were matching to the Center for Disease Control and Prevention (CDC) definitions [22].

\section{Identification of bacterial isolates}

After hospitalizing, hospitalized patients would be followed-up in order to identify the cause of the infection, which requires sampling and transferring them to laboratory. In the continuation of this process, after diagnosing the cause of the infection, it is the duty of the laboratory to determine the antibiotic resistance pattern to physician so that prescribe the most appropriate and effective antibiotic for treatment [23]. Samples including morning midstream urine, blood, stool, wound discharge, and respiratory samples were aseptically gathered via sterile containers and carried immediately to the Microbiology laboratory with proper transport media. Identity of bacteria was done via colony specifications, gram reaction, and divers biochemical examinations following standard methods [24]. Briefly, samples were grown on selective media including blood agar, MacConkey agar, and eosin methylene blue (EMB) medium. Then, bacterial identification of the isolates was performed according to the previously published [24].

\section{Antibiotics susceptibility test}

Confirmed isolates by biochemical tests underwent the disc diffusion susceptibility test based on the clinical and laboratory standards institute guidelines (CLSI) [25]. In short, a $0.5 \mathrm{McF}$ arland suspension of each isolate was inoculated on a whole plate surface Mueller-Hinton agar (Pronadisa, Spain) plate by streaking the swab in back and forth motions. Antimicrobial impregnated discs (Padtanteb, Iran) including co-trimoxazole $(1.25 / 23.75 \mu \mathrm{g})$, gentamycin $(10 \mu \mathrm{g})$, amikacin $(30 \mu \mathrm{g})$, ciprofloxacin $(5 \mu \mathrm{g})$, and erythromycin $(15 \mu \mathrm{g})$ to Gram positive isolates and ceftriaxone $(30 \mu \mathrm{g})$, ciprofloxacin $(5 \mu \mathrm{g})$, gentamycin $(10 \mu \mathrm{g})$, nalidixic acid $(30 \mu \mathrm{g})$, and nitrofurantoin $(300 \mu \mathrm{g})$ and co-trimoxazole $(1.25 / 23.75 \mu \mathrm{g})$ to Gramnegative isolates were put on the surface of the agar, and the plates were incubated for $24 \mathrm{~h}$ at $37^{\circ} \mathrm{C}$. Following incubation, inhibition zone sizes to the nearest millimeter were measured using a ruler. Using published CLSI guidelines, susceptibility, or resistance of the organism to each tested drug was determined. Interpretation of antibiotic susceptibility to evaluated MDR and XDR isolates was performed based on the European center for disease prevention and control( ECDC) instructor as well [18]. E. coli ATCC 25922 and S. epidermidis ATCC 12228 were served as positive controls in all phenotypic procedures as well.

\section{Data analysis and interpretation}

Data were analyzed using SPSS 16.0 and results were presented through tables. This study was designed to estimate the prevalence rate of nosocomial bacterial agents with antimicrobial susceptibility patterns and determining the rate of XDR and MDR in isolated bacteria from Inpatient, thus we did not consider demographic information of patients.

\section{Result}

During 1-year study, 4029 samples with nosocomial infections were collected. Out of 509 obtained isolates, 481 (94.49\%) were gathered from urine, followed by 12 (2.35\%) respiratory system, $10(1.96 \%)$ blood, 5 (0.98\%) wound, and $1(0.19 \%)$ stool. Detailed data listed in Additional file 1, Additional file 2. The most common pathogens recognized in the urinary tract and bloodstream cultures were E. coli (98.3\%) and S. epidermidis (37.5\%) respectively, In addition, Acinetobacter spp. (100\%) and P. aeruginosa (22.2\%) were the most common organisms isolated from the respiratory system. Details of the prevalence of isolated bacteria from 
different samples are shown in Table 1. Antibiotic resistance patterns of Gram-negative bacteria showed that the highest resistance rate was against nalidixic acid $(67.2 \%)$ followed by co-trimoxazole (63.8\%), and the lowest rate, $17.8 \%$, was related to gentamicin respectively (Detailed data was presented in Table 2 ). P. aeruginosa and Acinetobacter spp. showed the most resistance to co-trimoxazole, ciprofloxacin, nalidixic acid, and nitrofurantoin. In addition, Klebsiella spp. displayed the highest resistance to ceftriaxone. Among Gram-positives, the greatest resistance was shown in erythromycin and co-trimoxazole with $89.6 \%$ and $81.2 \% \%$ respectively. On the other side, in Table 1 , the lowermost rates were linked to amikacin $(27.1 \%)$ and gentamicin $(25.0 \%)$ respectively. In this, Enterococcus faecalis (E. faecalis) showed $100 \%$ resistance to co-trimoxazole. Beyond that, E. faecalis was approximately resistant to all selected antibiotics except amikacin. Among Gram-negatives base on susceptibility testing results, $370(80.5 \%)$ and 264 (57.3\%) isolated strains were categorized as MDR and XDR strain respectively. Among Gram-positives according to susceptibility testing results, 44 (91.7\%) and 35 (72.9\%) isolated strains were also classified as MDR and XDR strain respectively. (Data are presented in Additional file 3, Additional file 4). According to our study design, the frequencies of nosocomial bacterial agents, antimicrobial susceptibility patterns and the rate of XDR and MDR in Inpatient were the priority of the current study. Therefore investigating any correlations with patient characteristics were out of this study goals.

\section{Discussion}

Hospitals should have a pliable, naive, and regularly updated antibiotic-prescribing policy on a disease specific basis, relying whenever possible on knowledge of prevailing antibiotic-sensitivity patterns and controlled use of reserve antibiotics. This should incorporate local practice guidelines [23]. The microbiology laboratory has a major role in antimicrobial resistance decline that some of which are briefly mentioned: carrying out antibiotic susceptibility testing of appropriate microbial isolates consistent with standards, specifying which antibiotics are tested and reported for each organism, performing extra antibiotics testing for selected resistant bacteria, monitoring and reporting the prevalence of bacterial resistance to antimicrobial agents, limiting use of topical antibiotics and ensuring proper use of antibiotics (optimal choice, dosage and duration of antimicrobial therapy and chemoprophylaxis according to defined hospital antibiotic policy, and up-to-date antimicrobial guidelines) [23]. Organizational information about occupational infectious risks, exposures, and illnesses with occupational health services is regularly reviewed, updated, and are available in every hospital department. There must also be effective support at the national and regional levels [23]. Accordingly develop a system for identifying, investigating, reporting, analyzing, and controlling Healthcare-associated infection by giving some clues to a physician related to the suitable use of antibiotics and expanding antibiotic policies when antibiotic-resistant strains are detected could be essential [23]. Our study indicates a high prevalence $(12.63 \%)$ of nosocomial infections in our hospital and in overall a high antibiotic resistance in the form of

Table 1 Isolation rates of bacteria considering clinical specimens ( $\mathrm{n} \%)$

\begin{tabular}{|c|c|c|c|c|c|c|}
\hline Bacterial isolates & Urine & Blood & Wound & Respiratory & Stool & Total \\
\hline E. coli & 354 (98.3\%) & $5(1.38 \%)$ & $1(0.2 \%)$ & $0(0 \%)$ & $0(0 \%)$ & $360(100 \%)$ \\
\hline Citribacter spp & $25(100 \%)$ & $0(0 \%)$ & $0(0 \%)$ & $0(0 \%)$ & $0(0 \%)$ & $25(100 \%)$ \\
\hline Klebsiella spp & $34(77.2 \%)$ & $1(2.27 \%)$ & $2(4.54 \%)$ & 7 (15.9\%) & $0(0 \%)$ & $44(100 \%)$ \\
\hline Enterobacter spp & $16(100 \%)$ & $0(0 \%)$ & $0(0 \%)$ & $0(0 \%)$ & $0(0 \%)$ & $16(100 \%)$ \\
\hline Serratia & 1 (100\%) & $0(0 \%)$ & $0(0 \%)$ & $0(0 \%)$ & $0(0 \%)$ & 1 (100\%) \\
\hline Proteus spp & $2(100 \%)$ & $0(0 \%)$ & $0(0 \%)$ & $0(0 \%)$ & $0(0 \%)$ & $2(100 \%)$ \\
\hline$P$. aeruginosa & 7 (77.8\%) & $0(0 \%)$ & $0(0 \%)$ & $2(22.2 \%)$ & $0(0 \%)$ & $9(100 \%)$ \\
\hline Acinetobacter & $0(0 \%)$ & $0(0 \%)$ & $0(0 \%)$ & $3(100 \%)$ & $0(0 \%)$ & $3(100 \%)$ \\
\hline Shigella sonnei & $0(0 \%)$ & $0(0 \%)$ & $0(0 \%)$ & $0(0 \%)$ & $1(100 \%)$ & 1 (100\%) \\
\hline S. aureus & 20 (86.9\%) & $1(4.34 \%)$ & 2 (8.69\%) & $0(0 \%)$ & $0(0 \%)$ & $23(100 \%)$ \\
\hline S. saprophyticus & $10(100 \%)$ & $0(0 \%)$ & $0(0 \%)$ & $0(0 \%)$ & $0(0 \%)$ & $10(100 \%)$ \\
\hline S. epidermidis & 5 (62.5\%) & $3(37.5 \%)$ & $0(0 \%)$ & $0(0 \%)$ & $0(0 \%)$ & $8(100 \%)$ \\
\hline E. faecalis & $4(100 \%)$ & $0(0 \%)$ & $0(0 \%)$ & $0(0 \%)$ & $0(0 \%)$ & $4(100 \%)$ \\
\hline S. agalactiae & $3(100 \%)$ & 0 (0\%) & $0(0 \%)$ & $0(0 \%)$ & $0(0 \%)$ & $3(100 \%)$ \\
\hline Total & 481 (94.49\%) & $10(1.96 \%)$ & $5(0.98 \%)$ & $12(2.35 \%)$ & $1(0.19 \%)$ & $509(100.0 \%)$ \\
\hline
\end{tabular}


Table 2 Antibiotic susceptibility testing of Isolated strains

\begin{tabular}{|c|c|c|c|c|c|c|c|c|c|c|c|}
\hline \multicolumn{12}{|c|}{ (n\%) Antibiotic susceptibility patterns } \\
\hline $\begin{array}{l}\text { Bacterial } \\
\text { isolates }\end{array}$ & & & SXT & GM & AN & NA & CRO & $\mathrm{CP}$ & FM & $\mathrm{CN}$ & $E$ \\
\hline \multirow[t]{15}{*}{$\mathrm{G}+$} & \multirow[t]{3}{*}{ S. aureus } & $S$ & $3(13.0 \%)$ & $10(43.5 \%)$ & $16(69.6 \%)$ & ND & ND & $10(43.5 \%)$ & ND & $2(8.7 \%)$ & $0(0 \%)$ \\
\hline & & । & $1(4.3 \%)$ & $9(39.1 \%)$ & $3(13.0 \%)$ & ND & ND & $3(13.0 \%)$ & ND & $6(26.1 \%)$ & $1(4.3 \%)$ \\
\hline & & $\mathrm{R}$ & $19(82.6 \%)$ & $4(17.4 \%)$ & $4(17.4 \%)$ & ND & ND & $10(43.5 \%)$ & ND & $15(65.2 \%)$ & $22(95.7 \%)$ \\
\hline & \multirow[t]{3}{*}{ S. saprophyticus } & S & $3(30.0 \%)$ & $3(30.0 \%)$ & $9(90.0 \%)$ & ND & ND & $4(40.0 \%)$ & ND & $8(80.0 \%)$ & $2(20.0 \%)$ \\
\hline & & । & $1(10.0 \%)$ & $4(40.0 \%)$ & $0(0 \%)$ & ND & ND & $3(30.0 \%)$ & ND & $1(10.0 \%)$ & $1(10.0 \%)$ \\
\hline & & $\mathrm{R}$ & $6(60.0 \%)$ & $3(30.0 \%)$ & $1(10.0 \%)$ & ND & ND & $3(30.0 \%)$ & ND & $1(10.0 \%)$ & 7 (70.0\%) \\
\hline & \multirow[t]{3}{*}{ S. epidermidis } & S & $1(12.5 \%)$ & $5(62.5 \%)$ & $3(37.5 \%)$ & ND & ND & $3(37.5 \%)$ & ND & $3(37.5 \%)$ & $0(0 \%)$ \\
\hline & & । & $0(0 \%)$ & $1(12.5 \%)$ & $0(0 \%)$ & ND & ND & $0(0 \%)$ & ND & $2(25.0 \%)$ & $0(0 \%)$ \\
\hline & & $\mathrm{R}$ & $7(87.5 \%)$ & $2(25.0 \%)$ & $5(62.5 \%)$ & ND & ND & $5(62.5 \%)$ & ND & $3(37.5 \%)$ & $8(100.0 \%)$ \\
\hline & \multirow[t]{3}{*}{ E. faecalis } & S & $0(0 \%)$ & $1(25.0 \%)$ & $2(50.0 \%)$ & ND & ND & $0(0 \%)$ & ND & $0(0 \%)$ & $0(0 \%)$ \\
\hline & & । & $0(0 \%)$ & $0(0 \%)$ & $0(0 \%)$ & ND & ND & $0(0 \%)$ & ND & $1(25.0 \%)$ & $0(0 \%)$ \\
\hline & & $\mathrm{R}$ & $4(100 \%)$ & $3(75.0 \%)$ & $2(50.0 \%)$ & ND & ND & $4(100.0 \%)$ & ND & $3(75.0) \%$ & $4(100.0 \%)$ \\
\hline & \multirow[t]{3}{*}{ E. faecalis } & S & $0(0 \%)$ & $2(66.7 \%)$ & $2(66.7 \%)$ & ND & ND & $2(66.7 \%)$ & ND & $2(66.7 \%)$ & $1(33.3 \%)$ \\
\hline & & । & $0(0 \%)$ & $1(33.3 \%)$ & $0(0 \%)$ & ND & ND & $1(33.3 \%)$ & ND & $0(0 \%)$ & $0(0 \%)$ \\
\hline & & $\mathrm{R}$ & $3(100.0 \%)$ & $0(0 \%)$ & $1(33.3 \%)$ & ND & ND & $0(0 \%)$ & ND & $1(33.3 \%)$ & $2(66.7 \%)$ \\
\hline \multirow[t]{27}{*}{ G- } & \multirow[t]{3}{*}{ E. coli } & S & $122(33.9 \%)$ & $101(28.1 \%)$ & ND & 88 (24.4\%) & $189(52.5 \%)$ & $224(62.2 \%)$ & 198 (55.0\%) & ND & $\mathrm{ND}$ \\
\hline & & । & $10(2.8 \%)$ & $195(54.2 \%)$ & ND & 45 (12.5\%) & $17(4.7 \%)$ & $16(4.4 \%)$ & $123(34.2 \%)$ & ND & ND \\
\hline & & $\mathrm{R}$ & $228(63.3 \%)$ & 64 (17.8\%) & ND & $227(63.1 \%)$ & $154(42.8 \%)$ & $120(33.3 \%)$ & 39 (10.8\%) & ND & ND \\
\hline & \multirow[t]{3}{*}{ Citribacter spp } & S & 7 (28.0\%) & $11(44.0 \%)$ & ND & $0(0 \%)$ & $11(44.0 \%)$ & $16(64.0 \%)$ & $10(40.0 \%)$ & ND & ND \\
\hline & & । & $2(8.0 \%)$ & $10(40.0 \%)$ & ND & $2(8.0 \%)$ & $2(8.0 \%)$ & $2(8.0 \%)$ & $12(48.0 \%)$ & ND & ND \\
\hline & & $\mathrm{R}$ & $16(64.0 \%)$ & $4(16.0 \%)$ & ND & 23 (92.0\%) & $12(48.0 \%)$ & $7(28.0 \%)$ & $3(12.0 \%)$ & ND & ND \\
\hline & \multirow[t]{3}{*}{ Klebsiella spp } & S & $12(27.3 \%)$ & $10(22.7 \%)$ & ND & $6(13.6 \%)$ & 15 (34.1\%) & 27 (61.4\%) & 15 (34.1\%) & ND & ND \\
\hline & & । & 4 (9.1\%) & $22(50.0 \%)$ & ND & $6(13.6 \%)$ & $1(2.3 \%)$ & $1(2.3 \%)$ & $6(13.6 \%)$ & ND & ND \\
\hline & & $\mathrm{R}$ & 28 (63.6\%) & $12(27.3 \%)$ & ND & $32(72.7 \%)$ & 28 (63.6\%) & $16(36.4 \%)$ & $23(52.3 \%)$ & ND & ND \\
\hline & \multirow[t]{3}{*}{ Enterobacter spp } & $S$ & $5(31.2 \%)$ & $5(31.2 \%)$ & ND & $1(6.2 \%)$ & $3(18.8 \%)$ & $9(56.2 \%)$ & $8(50.0 \%)$ & ND & ND \\
\hline & & I & $2(12.5 \%)$ & $3(18.8 \%)$ & ND & $2(12.5 \%)$ & $2(12.5 \%)$ & $0(0 \%)$ & $4(25.0 \%)$ & ND & ND \\
\hline & & $\mathrm{R}$ & $9(56.2 \%)$ & $8(50.0 \%)$ & ND & $13(81.2 \%)$ & $11(68.8 \%)$ & $7(43.8 \%)$ & $4(25.0 \%)$ & ND & ND \\
\hline & \multirow[t]{3}{*}{ Serratia } & S & $1(100.0 \%)$ & $0(0 \%)$ & ND & $0(0 \%)$ & $1(100.0 \%)$ & $1(100.0 \%)$ & 0 (0\%) & ND & ND \\
\hline & & । & $0(0 \%)$ & $1(100 \%)$ & ND & $0(0 \%)$ & $0(0 \%)$ & $0(0 \%)$ & $1(100.0 \%)$ & ND & ND \\
\hline & & $\mathrm{R}$ & $0(0 \%)$ & $0(0 \%)$ & ND & $1(100.0 \%)$ & $0(0 \%)$ & $0(0) \%$ & $0(0 \%)$ & ND & ND \\
\hline & \multirow[t]{3}{*}{ Proteus spp } & S & $1(50.0 \%)$ & $1(50.0 \%)$ & ND & $0(0 \%)$ & $2(100.0 \%)$ & $2(100.0 \%)$ & $0(0 \%)$ & ND & ND \\
\hline & & I & $0(0 \%)$ & $1(50.0 \%)$ & ND & $1(50 \%)$ & $0(0 \%)$ & $0(0 \%)$ & $0(0 \%)$ & ND & ND \\
\hline & & $\mathrm{R}$ & $1(50.0 \%)$ & $0(0 \%)$ & ND & $1(50 \%)$ & $0(0 \%)$ & $0(0 \%)$ & $2(100.0 \%)$ & ND & ND \\
\hline & \multirow[t]{3}{*}{ P. aeruginosa } & S & $0(0 \%)$ & $2(22.2 \%)$ & ND & $0(0 \%)$ & $2(22.2 \%)$ & $4(44.4 \%)$ & $0(0 \%)$ & ND & ND \\
\hline & & । & $0(0 \%)$ & $3(33.3 \%)$ & ND & $0(0 \%)$ & $2(22.2 \%)$ & $1(11.1 \%)$ & $0(0 \%)$ & ND & ND \\
\hline & & $\mathrm{R}$ & $9(100 \%)$ & $4(44.4 \%)$ & ND & 9 (100.0\%) & $5(55.6 \%)$ & $4(44.4 \%)$ & $9(100.0 \%)$ & ND & ND \\
\hline & \multirow[t]{3}{*}{ Acinetobacter } & S & $0(0 \%)$ & $0(0 \%)$ & ND & $0(0 \%)$ & $0(0 \%)$ & $2(66.7 \%)$ & $1(33.3 \%)$ & ND & ND \\
\hline & & I & $0(0 \%)$ & $2(66.7 \%)$ & ND & $0(0 \%)$ & $0(0 \%)$ & $2(66.7 \%)$ & $0(0 \%)$ & ND & ND \\
\hline & & $\mathrm{R}$ & $3(100 \%)$ & $1(33.3 \%)$ & ND & $3(100.0 \%)$ & $3(100.0 \%)$ & $1(33.1 \%)$ & $2(66.7 \%)$ & ND & ND \\
\hline & \multirow[t]{3}{*}{ Shigella sonnei } & S & $0(0 \%)$ & $1(100.0 \%)$ & ND & $0(0 \%)$ & $1(100.0 \%)$ & $0(0 \%)$ & $0(0 \%)$ & ND & ND \\
\hline & & । & $0(0 \%)$ & $0(0 \%)$ & ND & $0(0 \%)$ & $0(0 \%)$ & $0(0 \%)$ & 1 (100.0\%) & ND & ND \\
\hline & & $\mathrm{R}$ & 1 (100.0\%) & $0(0 \%)$ & ND & $1(100.0 \%)$ & $0(0 \%)$ & $1(100.0 \%)$ & $0(0 \%)$ & ND & ND \\
\hline
\end{tabular}


MDR and XDR (81.5\%) among the pathogens. In the present research, the most frequencies of bacteria were E. coli, Klebsiella spp, Citrobacter spp, S. aureus, Enterobacter spp, S. saprophyticus, P. aeruginosa, S. epidermidis, E. faecalis, Acinetobacter spp, S. agalactiae, Proteus spp, Serratia marcescens, and Shigella sonnei respectively. In this study, the most common isolated bacteria were E. coli (70.7\%), Klebsiella spp (8.6\%), and Citrobacter spp (4.9\%) and S. aureus (4.9\%). other Iranian study conducted by Zahedi et al. was in line with our study [26]. On the other side, P. aeruginosa and Acinetobacter spp were detected as the most common bacteria by Davoudi et al. [27]. Another study performed in Iran, approved our study in this research, Klebsiella spp, $P$. aeruginosa and $E$. coli were more prevalent than other bacteria [28]. Farshid Rahimi-Bashar et al.performed a research in Iran and emphasized that $E$. coli is the most common strain followed by Klebsiella spp and this is in conformity with the results obtained in this study [29]. Study after study has shown that the UTI is the most frequent nosocomial infection in the world [30] and our study imply this subject and this is consistent with our study, because we also had the most nosocomial infections in UTI. As shown in Table 2, the nalidixic acid, co-trimoxazole were respectively the top two least effective antibiotics in the present study, and nitrofurantoin, gentamicin and amikacin were the lowest rate of resistance. Our study, similar to another Iranian research [31], showed the high efficiency of amikacin, and gentamycin for the treatment of nosocomial infections in Iran. Another study performed by Rajabi et al. was inconformity with the result of our work and the most prevalent bacteria was Acinetobacter spp and the most type of infection was respiratory system infections and he highest resistance rate was against ciprofloxacin [32]. Similar to our results, in the study of Zamani et al., gram-negative bacteria were the most frequent causes of nosocomial infections [33]. Similarly, in a survey performed on nosocomial UTI in a hospital, E. coli was the most isolated bacteria followed by Klebsiella spp [34]. These results were also shown in similar studies in Iran $[35,36]$ and other countries [37-39]. In contrast with our results, some studies in the United States [40] and Italy [41] reported $P$. aeruginosa and $S$. aureus as the most common pathogens. In 2012, and 2017some cross-sectional studies in Sudan and Iran have reported the percentage of MDR Enterobacteriaceae isolates spp., like $92.2 \%$, and $74 \%$. Frequencies of MDR isolated E. coli (66.6\%), K. pneumoniae (95.8\%), and Enterobacter spp., (80\%) strain in 2015 were reported in a cross-sectional published study in Iran as well [42]. In our findings, MDR and XDR isolates were more assessed in Klebsiella sp., (93.1\% and
79.5\%) and E. coli (76.1\% and 52.2\%) too. Considering the sample size our finding shown similarities to mentioned studies in Iran and reconfirmed them [42].

As a result, high prevalence of MDR and XDR strains in the northwest of Iran regions is a serious issue in hospital wards. These findings insist on systematic effort to educate and persuade prescribers of antimicrobials to follow evidence-based prescribing, in order to stem antibiotic overuse, and thus antimicrobial resistance.

\section{Limitation}

Responsible genes to antibiotic resistance, genetic relationship between the resistant strains, and investigating any correlations with patient characteristics are not determined and these are the limitation of this study. Moreover, identification of isolates merely performed taking advantage of biochemical aspect.

\section{Supplementary Information}

The online version contains supplementary material available at https://doi. org/10.1186/s13104-021-05503-0.

Additional file 1: Frequency of positive and negative culture in clinical specienmence.

Additional file 2: Frequency and Percent of bacterial isolates recovered form hospitalized patients.

Additional file 3: Frequency of multi and extensively- drug resistant (MDR and XDR) Gram-negative isolated bacteria ( $\mathrm{n} \%)$

Additional file 4: Frequency of MDR and XDR Gram positive bacterial isolates ( $\mathrm{n} \%)$.

\section{Acknowledgements}

The authors are grateful for the support of colleagues in Bacteriology and virology Departments at Zanjan University of Medical Sciences.

\section{Authors' contributions}

Contributions of the authors in this study were as follow: HS: conceptualization, data collection, data curation, spss analyzing, writing, editing. SGK: data collection, data curation, writing, review and editing. MB: data collection, writing. MR: data collection. SR: data collection. MG: writing and proof reading, preparing to major revision file. BM: conceptualization, supervision, methodology, final editing. All authors read and approved the final manuscript.

\section{Funding}

Not applicable.

\section{Availability of data and materials}

All results of this study have been classified and maintained by a dissertation in the Zanjan University of medical Sciences. We have indeed provided all raw data on which our study is based. In addition, the datasets analysed during the current study available from the corresponding author on reasonable request.

\section{Declarations}

\section{Ethics approval and consent to participate}

This study was approved by Mazandaran University of Medical Sciences ethics committee. All procedures were performed based on the ethical statement IR.MAZUMS.REC.1398.017 meeting number at Mazandaran University of 
Medical Sciences. In the current study, all ethical guidelines including Ethics and Consent to participate from the parents have been collected.

\section{Consent to publication}

Not applicable.

\section{Competing interests}

The authors announce that they have no difference in interest.

\begin{abstract}
Author details
1 Department of Microbiology and Virology, School of Medicine, Zanjan University of Medical Sciences, Zanjan, Iran. ${ }^{2}$ Molecular Medicine Research Center, Hamadan University of Medical Sciences, Hamadan, Iran. ${ }^{3}$ Department of Microbiology, Qazvin University of Medical Sciences, Qazvin, Iran. ${ }^{4}$ Department of Anesthesiology, School of Medicine, Zanjan University of Medical Sciences, Zanjan, Iran. ${ }^{5}$ Department of Microbiology and Virology, School of Medicine, Mazandaran University of Medical Sciences, Mazandaran, Iran.
\end{abstract}

Received: 12 October 2020 Accepted: 26 February 2021

Published online: 09 March 2021

\section{References}

1. Vincent J-L. Nosocomial infections in adult intensive-care units. Lancet. 2003;361(9374):2068-77.

2. Pourakbari B, Rezaizadeh G, Mahmoudi S, Mamishi S. Epidemiology of nosocomial infections in pediatric patients in an Iranian referral hospital. J Prevent Med Hyg. 2012; 53(4).

3. Organization WH: Report on the burden of endemic health care-associated infection worldwide. 2011.

4. Khan HA, Baig FK, Mehboob R. Nosocomial infections: epidemiology, prevention, control and surveillance. Asian Pac J Trop Biomed. 2017;7(5):478-82.

5. Mohajeri P, Azizkhani S, Farahani A, Norozi B. Genotyping of coa and aroA Genes of methicillin-resistant staphylococcus aureus strains isolated from nasal samples in western Iran. Jundishapur J Microbiol. 2016. https://doi. org/10.5812/jjm.26460.

6. System NNIS. National Nosocomial Infections Surveillance (NNIS) System report, data summary from January 1990-May 1999, issued June 1999. Am J Infect Control. 1999;27(6):520-32.

7. Endalafer N, Gebre-Selassie S, Kotiso B. Nosocomial bacterial infections in a tertiary hospital in Ethiopia. J Infect Prevent. 2011;12(1):38-43.

8. Raka L, Zoutman D, Mulliqi G, Krasniqi S, Dedushaj I, Raka N, Ahmeti S, Shala M, Vishaj A, Elezi Y. Prevalence of nosocomial infections in high-risk units in the university clinical center of Kosova. Infect Control Hosp Epidemiol. 2006;27(4):421-3.

9. Farr BM, Salgado CD, Karchmer TB, Sherertz RJ. Can antibiotic-resistant nosocomial infections be controlled? Lancet Infect Dis. 2001;1 (1):38-45.

10. Anderson DJ, Engemann JJ, Harrell LJ, Carmeli Y, Reller LB, Kaye KS. Predictors of mortality in patients with bloodstream infection due to ceftazidime-resistant Klebsiella pneumoniae. Antimicrob Agents Chemother. 2006;50(5):1715-20.

11. Cosgrove SE, Sakoulas G, Perencevich EN, Schwaber MJ, Karchmer AW, Carmeli Y. Comparison of mortality associated with methicillin-resistant and methicillin-susceptible Staphylococcus aureus bacteremia: a metaanalysis. Clin Infect Dis. 2003;36(1):53-9.

12. Roberts RR, Hota B, Ahmad I, Scott RD, Foster SD, Abbasi F, Schabowski S, Kampe LM, Ciavarella GG, Supino M. Hospital and societal costs of antimicrobial-resistant infections in a Chicago teaching hospital: implications for antibiotic stewardship. Clin Infect Dis. 2009;49(8):1175-84.

13. Ibrahim EH, Sherman G, Ward S, Fraser VJ, Kollef MH. The influence of inadequate antimicrobial treatment of bloodstream infections on patient outcomes in the ICU setting. Chest. 2000;118(1):146-55.

14. Cohen AL, Calfee D, Fridkin SK, Huang SS, Jernigan JA, Lautenbach E, Oriola S, Ramsey KM, Salgado CD, Weinstein RA. Recommendations for metrics for multidrug-resistant organisms in healthcare settings: SHEA/HICPAC position paper. Infect Control Hosp Epidemiol. 2008;29(10):901-13.

15. Hidron Al, Edwards JR, Patel J, Horan TC, Sievert DM, Pollock DA, Fridkin SK. Antimicrobial-resistant pathogens associated with healthcareassociated infections: annual summary of data reported to the National
Healthcare Safety Network at the Centers for Disease Control and Prevention, 2006-2007. Infect Control Hosp Epidemiol. 2008;29(11):996-1011.

16. Falagas ME, Karageorgopoulos DE. Pandrug resistance (PDR), extensive drug resistance (XDR), and multidrug resistance (MDR) among Gramnegative bacilli: need for international harmonization in terminology. Clin Infect Dis. 2008;46(7):1121-2.

17. Park YK, Peck KR, Cheong HS, Chung D-R, Song J-H, Ko KS. Extreme drug resistance in Acinetobacter baumannii infections in intensive care units, South Korea. Emerg Infect Dis. 2009;15(8):1325.

18. Magiorakos A-P, Srinivasan A, Carey R, Carmeli Y, Falagas M, Giske C, Harbarth S, Hindler J, Kahlmeter G, Olsson-Liljequist B. Multidrugresistant, extensively drug-resistant and pandrug-resistant bacteria: an international expert proposal for interim standard definitions for acquired resistance. Clin Microbiol Infect. 2012;18(3):268-81.

19. Halaji M, Feizi A, Mirzaei A, Sedigh Ebrahim-Saraie H, Fayyazi A, Ashraf A, Havaei SA. The global prevalence of class 1 integron and associated antibiotic resistance in Escherichia coli from patients with urinary tract infections, a systematic review and meta-analysis. Microb Drug Resist. 2020;26(10):1208-18.

20. Halaji M, Shahidi S, Atapour A, Ataei B, Feizi A, Havaei SA. Characterization of extended-spectrum $\beta$-lactamase-producing uropathogenic Escherichia coli among Iranian kidney transplant patients. Infect Drug Resistance. 2020;13:1429

21. Zalipour M, Esfahani BN, Halaji M, Azimian A, Havaei SA. Molecular characterization of vancomycin-resistant Enterococcus faecalis among inpatients at Iranian University Hospitals: clonal dissemination of ST6 And ST422. Infect Drug Resist. 2019;12:3039.

22. Garner JS, Jarvis WR, Emori TG, Horan TC, Hughes JM. CDC definitions for nosocomial infections, 1988. Am J Infect Control. 1988;16(3):128-40.

23. Ducel G, Fabry J, Nicolle L. Prevention of hospital acquired infections: a practical guide. Prevention of hospital acquired infections: a practical guide 2002(Ed. 2).

24. Cheesbrough M. District laboratory practice in tropical countries, part 2 Cambridge: Cambridge University Press; 2006.

25. Wayne P. Clinical and laboratory standards institute. Performance standards for antimicrobial susceptibility testing. 2011.

26. Zahedi M, Abounoori M, Maddah MM, Mirabi A, Sadeghnezhad R, Rezaei AA, Goli HR. Evaluation of bacterial nosocomial infections and antibiotic resistance pattern: a 2-year epidemiological surveillance study in a hospital population. Int J Med Investig. 2019;8(3):91-103.

27. Davoudi AR, Najafi N, Shirazi MH, Ahangarkani F. Frequency of bacterial agents isolated from patients with nosocomial infection in teaching hospitals of Mazandaran University of Medical Sciences in 2012. Caspian J Intern Med. 2014;5(4):227.

28. Bijari B, Abbasi A, Hemati M, Karabi K. Nosocomial infections and related factors in southern Khorasan hospitals. Iran J Med Microbiol. 2015;8(4):69-73.

29. Rahimi-Bashar F, Karami P, Khaledi A, Dehghan A, Seifrabie MA, Yaghoobi $\mathrm{MH}$. Evaluation of the prevalence of nosocomial infection in different wards of Be'sat hospital of Hamedan. Avicenna J Clin Microbiol Infect. 2018:5(2):31-5

30. Zahraei SM, Eshrati B, Asl HM, Pezeshki Z. Epidemiology of four main nosocomial infections in Iran during March 2007-March 2008 based on the findings of a routine surveillance system. Arch Iran Med. 2012;15(12):0-0.

31. Keihanian F, Saeidinia A, Abbasi K, Keihanian F. Epidemiology of antibiotic resistance of blood culture in educational hospitals in Rasht, North of Iran. Infect Drug Resist. 2018;11:1723.

32. Rajabi M, Abdar ME, Rafiei H, Aflatoonia MR, Abdar ZE. Nosocomial infections and epidemiology of antibiotic resistance in teaching hospitals in south east of Iran. Glob J Health Sci. 2016;8(2):190.

33. Zamani S, Nasiri MJ, Khoshgnab BN, Ashrafi A, Abdollahi A. Evaluation of antimicrobial resistance pattern of nosocomial and community bacterial pathogens at a teaching hospital in Tehran, Iran. Acta Medica Iranica 2014;182-186.

34. Soltani R, Ehsanpoor M, Khorvash F, Shokri D. Antimicrobial susceptibility pattern of extended-spectrum $\beta$-lactamase-producing bacteria causing nosocomial urinary tract infections in an Iranian referral teaching hospital. J Res Pharm Pract. 2014;3(1):6. 
35. Talebi TM, Golestanpour A. Symptomatic nosocomial urinary tract infection in ICU patients: identification of antimicrobial resistance pattern. 2009.

36. Saffar M, Enayti A, Abdolla I, Razai M, Saffar H. Antibacterial susceptibility of uropathogens in 3 hospitals, Sari, Islamic Republic of Iran, 2002-2003. EMHJ-Eastern Mediter Health J. 2008;14(3):556-63.

37. Weinstein RA, Gaynes R, Edwards JR, System NNIS. Overview of nosocomial infections caused by gram-negative bacilli. Clin Infect Dis. 2005;41(6):848-54.

38. Bouza E, San Juan R, Munoz P, Voss A, Kluytmans J. Infections C-oGotESGoN: a European perspective on nosocomial urinary tract infections II. Report on incidence, clinical characteristics and outcome (ESGINI-04 study). Clin Microbiol Infect. 2001;7(10):532-42.

39. Tankhiwale SS, Jalgaonkar SV, Ahamad S, Hassani U. Evaluation of extended spectrum beta lactamase in urinary isolates. Indian J Med Res. 2004;120(6):553-6.
40. Richards MJ, Edwards JR, Culver DH, Gaynes RP. Nosocomial infections in medical intensive care units in the United States. Crit Care Med. 1999:27(5):887-92.

41. Luzzati R, Antozzi L, Bellocco R, Del PB, Mirandola M, Procaccio F, Cirillo F, Romiti P, Sarti A, Manani G. Prevalence of nosocomial infections in intensive care units in Triveneto area, Italy. Minerva Anestesiol. 2001;67(9):647-52.

42. Rezaei M, Akya A, Elahi A, Ghadiri K, Jafari S. The clonal relationship among the Citrobacter freundii isolated from the main hospital in Kermanshah, west of Iran. Iran J Microbiol. 2016;8(3):175.

\section{Publisher's Note}

Springer Nature remains neutral with regard to jurisdictional claims in published maps and institutional affiliations.
Ready to submit your research? Choose BMC and benefit from:

- fast, convenient online submission

- thorough peer review by experienced researchers in your field

- rapid publication on acceptance

- support for research data, including large and complex data types

- gold Open Access which fosters wider collaboration and increased citations

- maximum visibility for your research: over $100 \mathrm{M}$ website views per year

At BMC, research is always in progress.

Learn more biomedcentral.com/submissions 